\title{
Characterization and structural analysis of wild type and a non-abscission mutant at the development funiculus (Def) locus in Pisum sativum L
}

\author{
Kwadwo Owusu Ayeh ${ }^{\dagger 1}$, YeonKyeong Lee ${ }^{\dagger 1}$, Mike J Ambrose ${ }^{2}$ and \\ Anne Kathrine Hvoslef-Eide*1
}

\author{
Address: ${ }^{1}$ Department of Plant and Environmental Sciences, Norwegian University of Life Sciences, PO BOX 5003, 1432 Aas, Norway and \\ ${ }^{2}$ Department of Crops Genetics, John Innes Centre, Norwich Research Park, Colney Lane, NR4 7UH Norwich, UK \\ Email: Kwadwo Owusu Ayeh - kwawdo.owusu.ayeh@umb.no; YeonKyeong Lee - yeonkyeong.lee@umb.no; \\ Mike J Ambrose - mike.ambrose@bbsrc.ac.uk; Anne Kathrine Hvoslef-Eide* - trine.hvoslef-eide@umb.no \\ * Corresponding author †Equal contributors
}

Published: 23 June 2009

BMC Plant Biology 2009, 9:76 doi:10.1 I86/147/-2229-9-76
Received: 25 August 2008

Accepted: 23 June 2009

This article is available from: http://www.biomedcentral.com/I47I-2229/9/76

(C) 2009 Ayeh et al; licensee BioMed Central Ltd.

This is an Open Access article distributed under the terms of the Creative Commons Attribution License (http://creativecommons.org/licenses/by/2.0), which permits unrestricted use, distribution, and reproduction in any medium, provided the original work is properly cited.

\begin{abstract}
Background: In pea seeds (Pisum sativum L.), the Def locus defines an abscission event where the seed separates from the funicle through the intervening hilum region at maturity. A spontaneous mutation at this locus results in the seed failing to abscise from the funicle as occurs in wild type peas. In this work, structural differences between wild type peas that developed a distinct abscission zone (AZ) between the funicle and the seed coat and non-abscission def mutant were characterized.

Results: A clear abscission event was observed in wild type pea seeds that were associated with a distinct double palisade layers at the junction between the seed coat and funicle. Generally, mature seeds fully developed an AZ, which was not present in young wild type seeds. The AZ was formed exactly below the counter palisade layer. In contrast, the palisade layers at the junction of the seed coat and funicle were completely absent in the def mutant pea seeds and the cells in this region were seen to be extensions of surrounding parenchymatous cells.

Conclusion: The Def wild type developed a distinct AZ associated with palisade layer and counterpalisade layer at the junction of the seed coat and funicle while the def mutant pea seed showed non-abscission and an absence of the double palisade layers in the same region. We conclude that the presence of the double palisade layer in the hilum of the wild type pea seeds plays an important structural role in AZ formation by delimiting the specific region between the seed coat and the funicle and may play a structural role in the $A Z$ formation and subsequent detachment of the seed from the funicle.
\end{abstract}

\section{Background}

Abscission is the controlled removal of a plant organ from the main plant body $[1,2]$. In some cases, abscission occurs at an early stage of development, a phenomenon that can be described as premature abscission. The abscission process may be an adaptive strategy of the main plant body in response to environmental stress such as temperature, disease, water, light quality and nutrition which 
adversely affect the parent plant body [1]. In pepper (Capsicum annuum L.), Gonzalez-Dugo et al. [3] suggested that high temperatures may be the reason for flower abscission whereas fruit abscission was reported during cold temperatures in Lonicera maacki [4]. In pea (Pisum sativum L.), high temperatures have been suggested as disrupting the development of reproductive organs leading to their abscission [5]. It has also been reported that some plants undergo floral and fruit abscission ostensibly to remove organs from the plant so that competition for pollinators and carbon assimilates are reduced [6,7]. In addition, endogenous factors such as phytohormones, auxin and ethylene and more importantly the disruptive role by either ethylene on auxin or vice versa, may play a key regulatory function in abscission [8-10].

Abscission occurs in predestined areas or positions on the plant and are referred to as abscission zones (AZ) $[11,12]$. The AZ is made up of multicellular structures which are morphologically distinct from surrounding cells and are formed in a few or up to several cell layers $[9,13]$. For example, the AZ in leaflets of Sambucus nigra is made up of 20-30 cell layers [14]. The cells in the AZ become larger and this is followed by dissolution of the middle lamella. The process occurs through the action of hydrolytic enzymes such as polygalacturonase [15-18] and $\beta$-endoglucanase [19-21]. These hydrolytic enzymes are believed to dissolve the middle lamella, which function by cementing neighboring cells together, resulting in cell separation processes [22].

Abscission is of crucial importance in both agriculture and horticulture. When fruits and seeds undergo abscission, they provide an efficient and effective means of dispersal and propagation so that plants are maintained from generation to generation. However, premature abscission may result in loss of yield. The identification and manipulation of traits and processes that influence fruit and seed dispersal are therefore of great interest in the development of strategies for crop improvement through the reduction of yield losses [23]. The yield and harvestability of many agronomically important crop species have been greatly improved through selection and breeding for reduced shattering $[24,25]$.

Mutants with altered phenotypic appearance compared to the wild type, may provide valuable insights into elucidating and understanding the biochemical and structural basis of the abscission process [26]. Such mutants have been described and characterized in a wide range of plant species. In Arabidopsis, the Inflorescence Deficient in Abscission (IDA) gene has been implicated in causing the petals to remain on the main plant body without being shed [27]. The Never ripe tomato fails to undergo many processes associated with normal fruit ripening, including abscission [28-30]. Similarly, the jointless mutant of tomato fails to form abscission zones at pedicel midpoints as compared to wild type plants [31-33]. The Absmutant in Lupinus angustifolius cv. 'Danja' fails to abscise any organs despite an apparently normal pattern of growth and senescence [26]. In Arabidopsis, mutants dab11, dab2-1, dab3-1, dab3-2 and dab3-3 have all been shown to delay the abscission of floral parts [2] and an abscissionless leaf variety of pubescent birch has also been described [34].

Peas are one of the world's most important grain legumes and serve as a valuable protein source in the diet of humans and animals. According to the Bi-weekly Bulletin, Agriculture and Agri-Food Canada [35], dry pea production in the world has ranged between 12.5 million tones (Mt) in 1998-1999 to 9.9 Mt in 2002-2004 with France, Canada and the USA being the leading production countries. Abscission of pea seeds from the funicle helps ensure effective dispersal of seeds for food and cultivation. Significant loss of seeds however, can result from seed falling out of mature pods after heavy late season rains followed by high temperatures and dry winds which can cause the pods to split and open. While this is a relatively infrequent occurrence, loss in marginal growing regions has stimulated the evaluation of a mutation at the def locus into breeding programmes and a limited number of released varieties. The spontaneous def mutation in pea was first described by Rozental [36]. Original testcrosses revealed a simple monogenic recessive inheritance and the name and gene symbol (Def) for the locus of development funiculus [37-39]. The locus has been found to be located on the bottom end of linkage group VII corresponding to chromosome no. 4 [40-42]. Recently, von Stackelberg [43] used molecular marker techniques to map the def locus. However, detailed information on the structural basis of the def mutant has remained scarce.

In this study, structural analyses were employed to further characterize the non-abscission mutant (def) in two lines carrying the mutant allele and two lines carry the wild type (Def) allele.

\section{Results \\ Seed abscission in wild type and def mutant pea}

Phenotypic differences between seeds and pods of JI 116 (wild type Def) and JI 3020 (def mutant) were examined at different stages of development. In mature wild type pods, seed detachment normally occurs through the separation of the seed body from the funicle at a site referred to as the abscission zone (AZ) (Figure 1A). The distal end of the funicle (the end attached to pod wall) in wild type, does not become detached from the pod wall (Figure 1B). In the def mutant, the funicle was found to be accreted (strongly attached) to the seed at the same intervening 

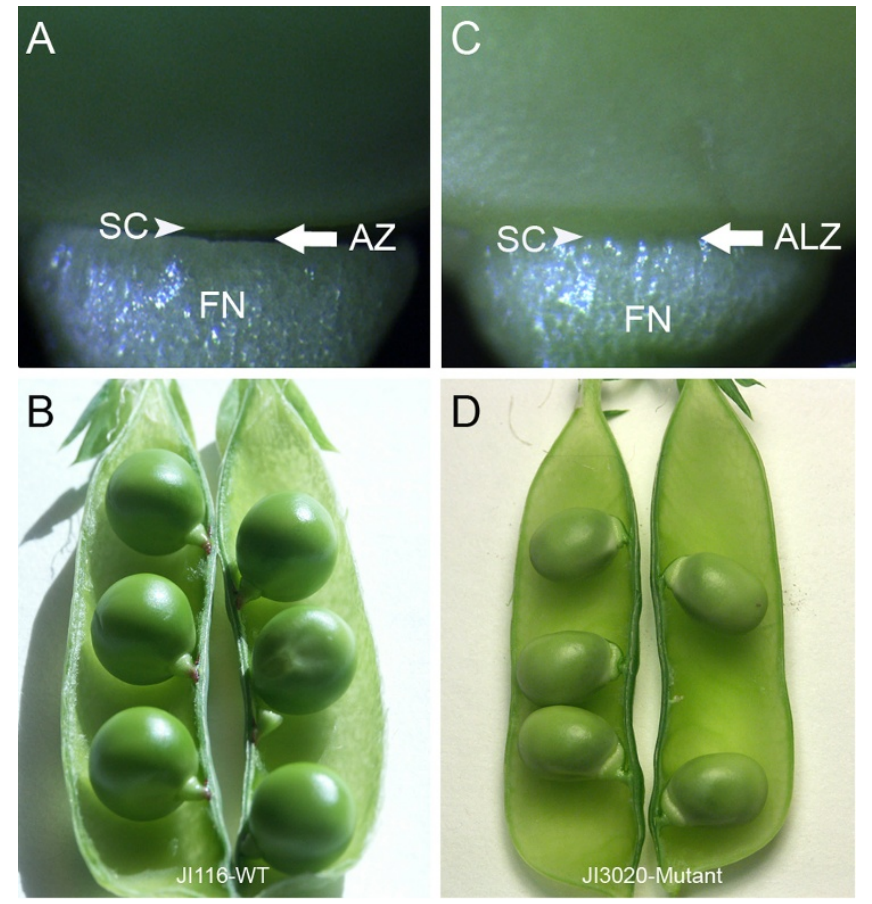

Figure I

Abscission zone (AZ) development in seeds of wild type pea JI I I 6 (A-B) and def mutant pea JI 3020 (CD). (A). Distinct $A Z$ development between funicle and seeds of the wild type pea. (B). Arrangement of pea seeds to the replum in a pod of the wild type pea. (C). Inseparable attachment of the seed to the funicle in the mutant pea. The intervening space which delimits the funicle from the seed is defined as the Abscissionless zone (ALZ). (D). Arrangement and attachment of pea seeds to the replum in a pod of the def mutant pea. The def mutant pea shows a swollen and thick funicle compared to the wild type. Arrows indicate the AZ and ALZ in the wild type and mutant, respectively; Arrow heads indicate seed coat; SC, Seed coat; AZ, Abscission zone; ALZ, Abscissionless zone

hilum region which can be described as an abscissionless zone (ALZ) (Figure 1C). In contrast to the wild type, seeds of the mutant had a slightly thickened funicle. Furthermore both the proximal and distal ends of the funicle remain firmly attached to the seed coat and the pod wall, respectively (Figure $1 \mathrm{D})$.

\section{Structural comparison of the seedlfunicle interface in wild type and def mutant pea seeds}

A structural comparison between wild type and def mutant pea seeds revealed that both the wild type lines (JI 116 and JI 2822) exhibited a distinct double palisade layer in the hilum region which served to define the AZ (Figure $2 \mathrm{~A}-\mathrm{D}, \mathrm{I}-\mathrm{L}$ ). The layer proximal to the seed, is described as the palisade layer whereas an opposing palisade layer is described as the counter palisade layer (Figure 2C and
2D). In young wild type seeds, cell separation was not observed (Figure 2A and 2C), the cells remaining intact and of regular round and compact form (Figure 2C). In maturing seeds, cell separation in the AZ occurred immediately below the counter palisade layer in the hilum region (Figure $2 \mathrm{~B}$ ) with cell separation starting in the middle and developed outwards to the epidermis of the funicle. These cells were characterized as being irregular and damaged (Figure 2D). In wild type JI 2822, the abscission process was again observed in seeds that were well into their maturation phase, at and around the time of maximum fresh weight and started at the midpoint where the counterpalisade layer was inconspicuous (Figure 2I-L). The same sequence of cell separation was observed in the wild type line JI116 with the cell separation process starting in the centre and extending outwards towards the epidermis of the AZ and the seed finally becoming separated from the funicle. In contrast, seeds of the mutant pea lines did not develop a distinct boundary region of a double palisade layer between the seed coat and the funicle (Figure 2E-F and Figure 2M-N). Moreover, no cell separation events were observed even in mature pea seed (Figure $2 \mathrm{~F}$ and $2 \mathrm{~N}$ ) thus the funicle remained firmly bound to the seed (Figure 2G-H and Figure 2O-P).

\section{Discussion \\ Abscission of seeds in wild type and mutant is controlled by Def loci}

The abscission process is defined as the shedding of organ parts such as leaves, flowers and fruits [12]. Our study focused on a structural comparison between the wild type and def mutant pea seed. These two pea types exhibited distinctively different phenotype and structural differences with respect to the region where the funicle abuts the hilum. The Def wild type lines underwent a normal abscission event between funicle and seed coat mediated by cell separation in a specific layer of cells immediately below the counter palisade layer. No abscission event occurred in the def mutant lines which lacked the double palisade in the hilum region. We conclude, therefore, that the Def locus is important in controlling the abscission event of pea seeds.

\section{Absence of the hilum palisade layers is the key characteristic in the def mutant pea seed}

Structural analysis revealed the absence of the palisade layer and counterpalisade layer underlying the funicle in def mutant pea seeds whereas the wild type showed a distinct double palisade layers at the same location. In the testas of wild type pea seeds, the palisade layers in the hilum take their origin from the outer integuments and are made up of macrosclereids [44] which are elongated perpendicular to the surface of the seed $[45,46]$. The testas of the mutant lines are similarly covered by a layer of macrosclereids, but this is not continued into funicle region 


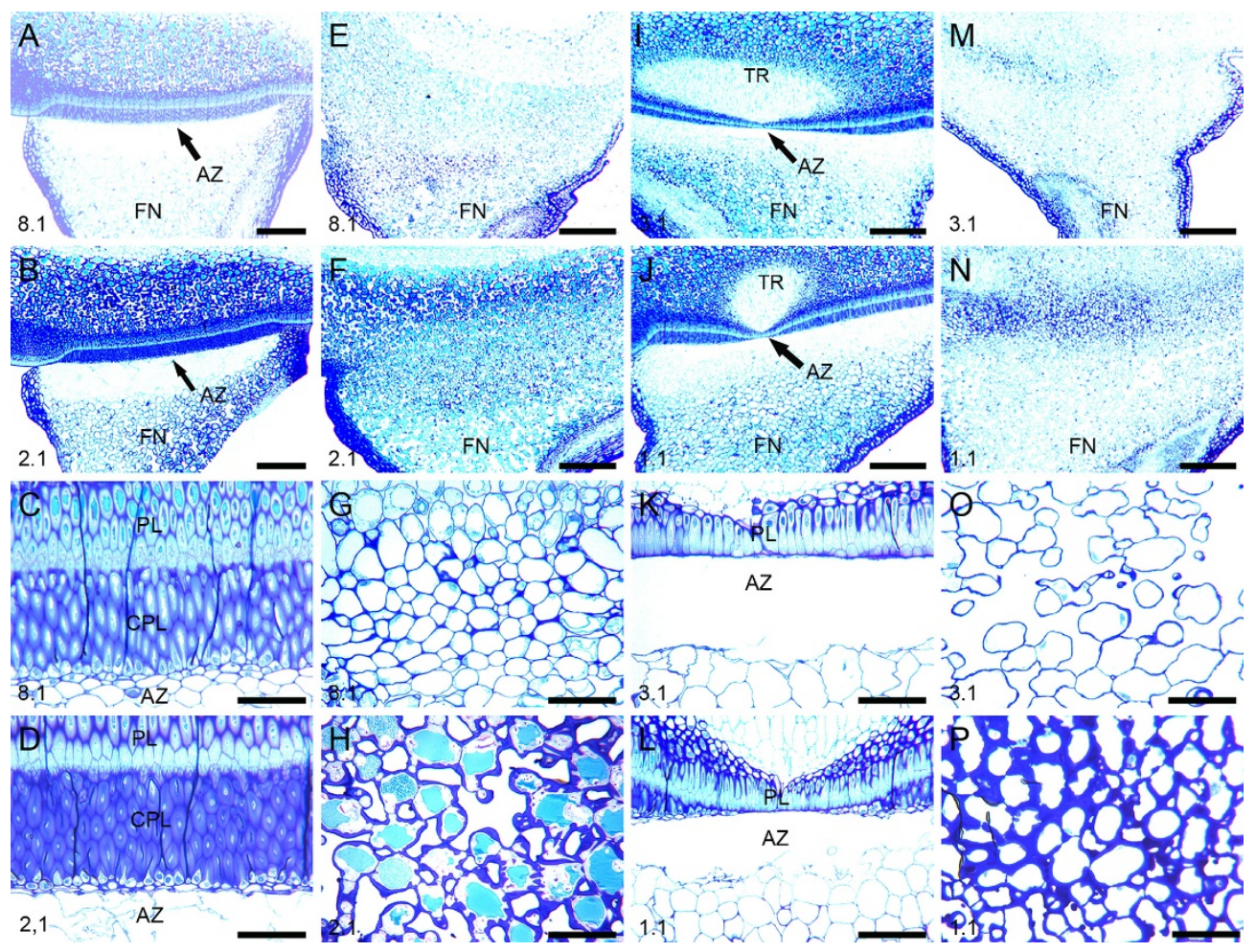

Figure 2

Light micrographs showing structural differences between two wild types and two def mutant pea lines. (A-D). The wild type (I I I6). (A) AZ development in young pea seed at stage 8.I and (B) In mature pea seed at 2.I. (C) Higher magnification of the $A Z$ development in the young pea seed in (A). (D) Higher magnification of the $A Z$ in the mature pea seed in (B). There is no sign of cell separation in young stage at 8 . I but distinct cell separation occurs in the mature stage at 2.I. (E-H) The def mutant type (JI I 84). (E) Non-abscission in young mutant pea seed at stage 8.I showing the absence of the hilum palisade layer. (F) Non-abscission in mature mutant seed at stage 2.I. (G-H) Higher magnifications of the abscissionless zones (ALZ) in young and mature seeds of the def mutant in $E$ and $F$, respectively. (I-L) The wild type (II 2822). (I) AZ development in the wild type pea at stage 3.I. (J) AZ development in the mature pea at stage I.I. (K-L) Higher magnification of the AZ in (I) and $(J)$, respectively. (M-P) The def mutant type (J 3020). (M) Non-abscission in young mutant pea seed at stage 3. I. (N) Mutant pea seed at stage I.I. (O-P) Higher magnification of the ALZ in (M) and (N), respectively. Seeds in the first (most mature) pod and close to pea stock are designated as I.I. The youngest pod and close to the pea stock is designated as 8 . I for JI II6, 8.I for JI I I 84, 3.I for JI 2822 and 3.I for JI 3020. AZ, Abscission zone; FN, Funicle; PL, Palisade layer; CPL, Counter palisade layer; TR, Tracheid bar. Scale bars = A, B, E, F, I, J, M and N = I2.5 $\mathrm{m}$; C, D, G, H, K, L, O and P= $25 \mu \mathrm{m}$.

which lacks any palisade structures. Although there is no direct evidence that the double palisade layer underlying the funicle is responsible for the abscission of seed from the funicle in the wild type pea, the absence of the double palisade layers in the non-abscission def mutant pea suggest that the palisade layers may play a key role in regulating the abscission process in some way.

The palisade layers in seeds are also responsible for water permeability. In seed development, seed maturation is accompanied with reducing moisture content in the seed [47]. The testa comprises of a layer of strengthened palisade cells and these cells which are implicated in controlling permeability both during development and at final maturity [48]. def mutant peas develop normal testas therefore the mutant is clearly not defective in making cells analogous to palisade cells that are normally found in the hilum region. Further study is necessary to probe the regulatory basis of the failure to develop the palisade layers underlying the funicle in def mutant seeds which would otherwise go on to develop an abscission event in wild type seeds.

\section{Cell separation process in the $A Z$ of wild type seed}

We have shown that the abscission of the seed from the funicle is initiated at the centre of the seed coat/palisade junction in the wild type line (JI 116) (Figure 2B and 2D). In JI 2822, the abscission event was also observed to start at the centre of the seed coat/palisade junction, particularly where the counterpalisade layer becomes restricted 
in the vicinity of the tracheid bar (Figures 2I and 2J). Although it is not shown, the other wild type and both mutant lines also possessed tracheid bars. The def mutant seeds were clearly able to develop and mature as fully functional seeds and the loss of the double palisade layer and failure to develop an $\mathrm{AZ}$ were not critical to their development.

The actual separation of cells in the AZ begins in the single layer of cells directly beneath the counter palisade layer and extends outwards as abscission proceeds. This is in contrast to poinsettia flower abscission, where active cell division and cell enlargement occur during the abscission process [49]. However, such cell divisions are not a prerequisite prior to abscission as in tobacco, tomato and several other solanaceous genera [50]. Like pea, these plants have a visible AZ long before abscission is initiated and do not shows cell expansion. Cell swelling has been suggested as assisting in breaking of the vascular strand [49,51]. In our study, it was hard to see cell expansion or cell swelling in the AZ as cells in the AZ were in very irregular conformation and cell walls frequently appeared damaged and broken. Although no enzyme assay was performed in this study, it is plausible to suggest that cells in the AZ may have been attacked by hydrolytic enzymes. This is especially the case where cell separation is accompanied with cell wall modification where the cell wall components disappear or are reconstruct. Many studies on enzyme activity during abscission have been focused on enzymes that provide cell wall dissolution $[20,21,52]$. Expression of such enzymes are dependent on maturity, leading to the dissolution of the middle lamella between adjacent cells [53]. The identification and localization of such enzymes in further studies into pea seed abscission offer a further role of the def mutant in helping to understand the cellular context in which genes that encode for such enzymes are transcribed and expressed.

\section{Conclusion}

This study provides a structural comparison of the distinct double palisade layer and the AZ found in the hilum region of wild type pea seeds and the absence of the double palisade and non abscission lines carrying the def mutant allele. These findings underline key regulation of the Def locus in controlling the abscission process through the correct development of the hilum double palisade layer as a prerequisite for $\mathrm{AZ}$ development in wild type pea seeds.

\section{Methods}

\section{Plant material}

The four lines of pea (Pisum sativum L.) seeds JI 116, JI 2822, JI 1184 and JI 3020 used in this study were selected on the basis of the presence of specific alleles at the Def locus, which control the detachment of the seed from the
Table I: Details of Pisum sativum accessions and their allelic status with respect to the Def locus.

\begin{tabular}{ccc}
\hline Accession & Name & Def allele \\
\hline JI II6 cv. Parvus & Def (wild type) \\
\hline JI 2822 & RIL, research line & Def (wild type) \\
\hline JIII84 & Priekuskij-34I-def & def (mutant) \\
\hline Jl 3020 & cv. Nord & def (mutant) \\
\hline
\end{tabular}

funicle (Table 1). JI 1184 originates from Rozenthal's collection from Russia where the def mutation was first identified and isolated and is an early line selected as carrying the def allele. It has been used for agronomic studies and is a sister line to the type line for def mutant allele. JI 3020 is a registered cultivar from the Netherlands that incorporates the same mutant def allele. In the absence of nearisogenic lines for the Def alleles, two well characterized lines (JI 116 and JI 2822) that matched the gross plant habit of the mutant lines were selected. Both these lines are well characterized genetically and were selected for use in genetic analysis of heterozygous Def/def seeds that are the subject of further study of this locus.

Seeds corresponding to each line were sown in pots with fertilised peat (Floralux, Nittedal Torvindustrier, Norway) and grown under greenhouse conditions at $22^{\circ} \mathrm{C}$ and $16 /$ $8 \mathrm{~h}$ photoperiod with a photon flux of $110 \mu \mathrm{mol} \mathrm{m}{ }^{-2} \mathrm{~s}^{-1}$ (400-700 nm Phosynthetic Active Radiation (PAR)) and a daylength extending light provided from incandescent lamps (OSRAM, Germany). Seeds and seedlings were watered six days a week and given a complete nutrient solution once a week.

\section{Plant tissue preparation and examination}

For structural analysis, seeds of all lines were embedded in LR White resin (London Resin Company, England). Seeds from each pod identification stage were transversely cut into $2 \mathrm{~mm}$ thick, from the funicle-seed coat interface. The cut material was further longitudinally cut into two pieces and immediately fixed in $1 \%$ formaldehyde, $0.025 \%$ glutaraldehyde, $0.1 \%(\mathrm{v} / \mathrm{v})$ Tween 20 in $0.01 \mathrm{M}$ sodium phosphate buffer, pH 7.2 and vacuum infiltrated for $1 \mathrm{~h}$. Fixed and infiltrated tissues were placed at $4^{\circ} \mathrm{C}$ overnight. The fixed samples were washed twice with sodium phosphate buffer for $4 \mathrm{~h}$. Washed samples were then dehydrated in a graded ethanol series. Infiltration was performed with a progressively increasing ratio of LR white resin to ethanol. At the end of the infiltration process, the specimens were transferred to an embedding mould and polymerised at $50^{\circ} \mathrm{C}$ for $24 \mathrm{~h}$. Plant materials 
embedded in LR white blocks were sectioned with a diamond knife (Diatome Ltd., Switzerland) on an ultramicrotome (Leica, Germany). Sections (1 $\mu \mathrm{m}$ thick) were placed on Vectabond (Vector Laboratories, USA) coated glass slides and heated at $55^{\circ} \mathrm{C}$ on a warm plate to adhere the sections to the slide. For histological staining, sectioned materials were stained with toluidine blue $\mathrm{O}$ (Sigma, USA), washed with distilled water and mounted in Depex (BDH, USA). Sections were examined using a Leica brightfield microscope (Leica, Germany).

\section{Authors' contributions}

KOA contributed to the growing of the plants, harvested materials, carried out the structural examination and drafted the manuscript. YKL participated in designing the experiments, structural analysis and the drafting of the manuscript. MA contributed with plant material, the general idea of the study and participated in revision of the manuscript. AKHE participated in the general idea of the study, the design of the experiments and contributed to the writing and revision of the paper. All authors have read and approved the final manuscript.

\section{Acknowledgements}

Kwadwo O. Ayeh wishes to thank The Norwegian Arabidopsis Research Centre (NARC) at The Norwegian University of Life Sciences (UMB) and Prof. Odd Arne Rognli for financial contribution. The authors would also like to thank Hilde R. Kolstad, Kari Boger and Tone Melby for technical support.

\section{References}

I. Addicott FT: Abscission. London, England: Univeristy of California Press, LTD; 1982.

2. Patterson SE, Bleecker AB: Ethylene-dependent and -independent processes associated with floral organ abscission in Arabidopsis. Plant Physiol 2004, I 34: 194-203.

3. Gonzalez-Dugo V, Orgaz F, Fereres E: Responses of pepper to deficit irrigation for paprika production. Sci Hort 2007, I | 4:77-82.

4. Bartuszevige AM, Hughes MR, Bailer AJ, Gorchov DL: Weatherrelated patterns of fruit abscission mask patterns of frugivory. Can J Bot 2006, 84:869-875.

5. Guilioni L, Wery J, Tardieu F: Heat stress-induced abortion of buds and flowers in pea: is sensitivity linked to organ age or to relations between reproductive organs? Ann Bot 1997, 80: $159-168$

6. Dal Cin V, Danesin M, Boschetti A, Dorigoni A, Ramina A: Ethylene biosynthesis and perception in apple fruitlet abscission (Malus domestica L. Borck). J Exp Bot 2005, 56:2995-3005.

7. Rogers HJ: Programmed cell death in floral organs: How and why do flowers die? Ann Bot 2006, 97:309-3I5.

8. Blanusa T, Else MA, Atkinson CJ, Davies WJ: The regulation of sweet cherry fruit abscission by polar auxin transport. Plant Growth Regul 2005, 45: I89-198.

9. Taylor JE, Whitelaw CA: Signals in abscission. New Phytol 200I, | 5 I:323-340.

10. Beyer EM Jr, Morgan PW: Abscission: The role of ethylene modification of auxin transport. Plant Physiol I 971, 48:208-2I2.

II. Sexton R, Roberts JA: Cell biology of abscission. Annu Rev Plant Physiol Plant Mol Biol 1982, 33: I33-162.

12. Gonzalez-Carranza ZH, Lozoya-Gloria E, Roberts JA: Recent developments in abscission: shedding light on the shedding process. Trends Plant Sci 1998, 3:10-14.

13. Bleecker AB, Patterson SE: Last exit: senescence, abscission, and meristem arrest in Arabidopsis. Plant Cell I997, 9: I I69-I I79.
14. Osborne DJ, Sargent JA: Positional differentiation of abscission zones during development of leaves of Sambucus nigra and response of cells to auxin and ethylene. Planta 1976, 132:197-204.

15. Gonzalez-Carranza ZH, Whitelaw CA, Swarup R, Roberts JA: Temporal and spatial expression of a polygalacturonase during leaf and flower abscission in oilseed rape and Arabidopsis. Plant Physiol 2002, I 28:534-543.

16. Kalaitzis $\mathrm{P}$, Solomos T, Tucker ML: Three different polygalacturonases are expressed in tomato leaf and flower abscission, each with a different temporal expression pattern. Plant Physiol I997, I I 3: I303-I308.

17. Bonghi C, Tonutti P, Ramina A: Biochemical and molecular aspects of fruitlet abscission. Plant Growth Regul 2000, 3 I:35-42.

18. Kalaitzis $\mathrm{P}$, Koehler SM, Tucker ML: Cloning of a tomato polygalacturonase expressed in abscission. Plant Mol Biol 1995, 28:647-656.

19. Taylor JE, Coupe SA, Picton S, Roberts JA: Charaterization and accumulation pattern of an messenger RNA encoding an abscission related $\beta$-I,4-glucanase from leaflets of Sambucus nigra. Plant Mol Biol 1994, 24:961-964.

20. Mishra A, Khare S, Trivedi PK, Nath P: Ethylene induced cotton leaf abscission is associated with higher expression of cellulase (GhCell) and increased activities of ethylene biosynthesis enzymes in abscission zone. Plant Physiol Biochem 2008, 46:54-63.

21. Brummell DA, Hall BD, Bennett AB: Antisense suppression of tomato endo-I,4- $\beta$-glucanase Cel2 mRNA accumulation increases the force required to break fruit abscission zones but does not affect fruit softening. Plant Mol Biol 1999, 40:615-622.

22. Carrillo-Lopez A, Cruz-Hernandez A, Carabez-Trejo A, GuevaraLara F, Paredes-Lopez O: Hydrolytic activity and ultrastructural changes in fruit skins from two prickly pear (Opuntia sp.) varieties during storage. I Agricult Food Chem 2002, 50:1681-1685.

23. Doebley J: Unfallen grains: How ancient farmers turned weeds into crops. Science 2006, 312:1318-1319.

24. Fuller DQ: Contrasting patterns in crop domestication and domestication rates: Recent archaeobotanical insights from the old world. Ann Bot 2007, 100:903-924.

25. Li C, Zhou A, Sang T: Rice domestication by reducing shattering. Science 2006, 3 I I: 1936-1939.

26. Clements J, Atkins C: Characterization of a non-abscission mutant in Lupinus angustifolius. I. Genetic and structural aspects. Am J Bot 200I, 88:31-42.

27. Butenko MA, Patterson SE, Grini PE, Stenvik GE, Amundsen SS, Mandal A, Aalen RB: Inflorescence deficient in abscission controls floral organ abscission in Arabidopsis and identifies a novel family of putative ligands in plants. Plant Cell 2003 I 5:2296-2307.

28. Tigchelaar EC, McGlasson WB, Buescher RW: Genetic regulation of tomato fruit ripening. Hortscience 1978, I3:508-5I3.

29. Lanahan MB, Yen HC, Giovannoni JJ, Klee HJ: The never ripe mutation blocks ethylene perception in tomato. Plant Cell 1994, 6:52I-530.

30. Rick CM, Butler L: Cytogenetics of the tomato. Adv Genet Incorp Mol Genet Med 1956, 8:267-382.

31. Szymkowiak EJ, Irish EE: JOINTLESS suppresses sympodial identity in inflorescence meristems of tomato. Planta 2006, 223:646-658.

32. Szymkowiak EJ, Irish EE: Interactions between jointless and wild type tomato tissues during development of the pedicel abscission zone and the inflorescence meristem. Plant Cell 1999, I I:159-175.

33. Butler L: Inherited characters in the tomato. II. Jointless pedicel. J Hered 1936, 27:25-26.

34. Rinne $\mathrm{P}$, Tuominen $\mathrm{H}$, Junttila $\mathrm{O}$ : Arreated leaf abscission in the nonabscising variety of pubescent birch - Developmental, morphological and hormonal aspects. J Exp Bot 1992, 43:975-982.

35. Bi weekly Bulletin: Dry Peas: Situation and outlook. Agricult Agrifood Can 2006, 19:1-3.

36. Rozental AJ: Novaya forma gorokha. Bobowyje i ziernobobowyje kultury Moskwa 1966:73-75.

37. Khangildin VK, Khangildin V: Nekotorye rezultaty geneticheskikh issledovanijs gorokhom. Voprosy genetiki i sjelekcji sjel- 
skohozjajstwienych rastieniejTrudy Bashkirskogo Nauchno-Issledovatelsta 1969:40-61.

38. Gandzelo NG, Khangildin VV: Investigation of new mutant genes in the pea .4. Diallele analysis of seed productivity of the nonshattering pea cultivars containing def gene. Genetika 1989, 25:659-665.

39. Khangildin WV, Nuriakhmetov DF: Identification of new mutant genes in the pea .3. The effect of def gene stipulating the nonshattering on combining ability, seed productivity and homeostasis in the system of tester crosses. Genetika 1988, 24:298-305.

40. Weeden NF, Ellis THN, Timmermann-Vaughan GM, Swiecicki WK, Rosov SM, Berdnikov VA: A consensus linkage map for Pisum sativum. Pisum Genet 1998, 30: I-4.

4I. Weeden NF, Wolko B: Linkage map for the garden pea (Pisum sativum) based on molecular markers. In Genetic Maps 5th edition. Edited by: O'brien SJ. Cold Spring Harbor, New York: Cold Spring Harbor Laboratory Press; 1990:6. 106-II2.

42. Swiecicki W, Wolko B: Locus for the gene def (DEVELOPMENT FUNICULUS). Pisum Newslett 1990, 22:67-68.

43. von Stackelberg M, Lindemann S, Menke M, Riesselmann S, Jacobsen $\mathrm{HJ}$ : Identification of AFLP and STS markers closely linked to the def locus in pea. Theor Appl Genet 2003, 106:1293-1299.

44. Harris WM: On the development of macrosclereids in seed coats of Pisum sativum L. Am J Bot 1983, 70:1528-1535.

45. Van Dongen JT, Ammerlaan AMH, Wouterlood M, Van Aelst AC Borstlap AC: Structure of the developing pea seed coat and the post-phloem transport pathway of nutrients. Ann Bot 2003, $91: 729-737$.

46. Corner E: The Leguminous seed. Phytomorphology 195I, I:II7-I50.

47. Hay FR, Probert RJ: Keeping seeds alive. In Seed technology and its biological basis Edited by: Black M, Bewley JD. Sheffield, UK: Academic Press; 2000:375-410.

48. Werker E: Seed coat. In Seed anayomy Edited by: Werker E. Berlin, Stuttgart: Capio Lumen; 1997:84-138.

49. Lee Y, Derbyshire P, Knox JP, Hvoslef-Eide AK: Sequential cell wall transformations in response to the induction of a pedicel abscission event in Euphorbia pulcherrima (poinsettia). Plant 2008, 54:993-1003.

50. Van Doorn WG, Stead AD: Abscission of flowers and floral parts. J Exp Bot 1997, 48:82।-837.

51. Oberholster SD, Peterson CM, Dute RR: Pedicel abscission of soybean - Cytological and ultrastructural changes induced by auxin and ethephon. Can J Bot |991, 69:2177-2186.

52. Roberts JA, Whitelaw CA, Gonzalez-Carranza ZH, McManus MT: Cell separation processes in plants - Models, mechanisms and manipulation. Ann Bot 2000, 86:223-235.

53. Tabuchi $\mathrm{T}$, Ito $\mathrm{S}$, Arai $\mathrm{N}$ : Anatomical studies of the abscission process in the tomato pedicels at flowering stage. J Jap Soc Horticul Sci 200I, 70:63-65.
Publish with Bio Med Central and every scientist can read your work free of charge

"BioMed Central will be the most significant development for disseminating the results of biomedical research in our lifetime. "

Sir Paul Nurse, Cancer Research UK

Your research papers will be:

- available free of charge to the entire biomedical community

- peer reviewed and published immediately upon acceptance

- cited in PubMed and archived on PubMed Central

- yours - you keep the copyright
BioMedcentral 